\title{
The Triple Helix of University-Industry-Government Relations
}

(February 2012)

\author{
Loet Leydesdorff \\ University of Amsterdam, Amsterdam School of Communication Research (ASCoR), \\ Kloveniersburgwal 48, 1012 CX Amsterdam, The Netherlands; \\ loet@ leydesdorff.net ; http://www.leydesdorff.net
}

\section{Introduction}

Etzkowitz \& Leydesdorff (2000) further elaborated the Triple Helix of University-IndustryGovernment Relations (cf. Etzkowitz \& Leydesdorff, 1995; Lowe, 1982) into a model for studying knowledge-based economies. A series of workshops, conferences, and special issues of journals have developed under this title since 1996. In various countries, the Triple Helix concept has also been used as an operational strategy for regional development and to further the knowledge-based economy; for example, in Sweden (Jacob, 2006) and Ethiopia (Saad et al., 2008). In Brazil, the Triple Helix became a "movement" for generating incubators in the university context (Almeida, 2005).

Normatively, a call for collaborations across institutional divides, and the awareness that the roles of partners in such collaborations are no longer fixed in a knowledge-based economy, provides a neo-corporatist model of economic and social development that is compatible with neo-liberalism (Mirowski \& Sent, 2007; cf. Rothwell \& Zegveld, 1981). The City of Amsterdam, for example, adapted the Triple Helix as its working model for economic development as 
recently as $2010 .^{1}$ In the Latin American context, the Triple Helix model accords with Sábato's (1975) "Triangle" as a program for endogenous development of technology and innovation. The emphasis on bottom-up learning processes (Bunders et al., 1999) can help to avoid reification of systems (or states and interstate dependency-relations) as barriers to innovation. In an overlay of communications between industrial, academic, and administrative discourses, new options and synergies can be developed that can strengthen knowledge integration at the regional level. In a study about regional innovation systems, Cooke \& Leydesdorff (2006), for example, noted the possibility of "constructed advantages."

\section{The Origins of the Triple Helix Model}

The Triple Helix thesis emerged from a confluence between Etzkowitz' longer-term interest in the study of university-industry relations (e.g., Etzkowitz, 2002) and Leydesdorff's interest in an evolutionary model that can generate a next-order hyper-cycle - or in terms of the TH, an overlay of communications (cf. Leydesdorff, 1995). After Etzkowitz' (1994) participation in a workshop and a proceedings volume, the metaphor of a Triple Helix emerged in discussions about organizing a follow-up conference under this title in Amsterdam in January 1996 (Etzkowitz \& Leydesdorff, 1995; cf. Lowe, 1982).

From a (neo-)evolutionary perspective, a double helix can be expected to generate a relatively stable trajectory when the two subdynamics mutually shape each other in a coevolution. For example, in a political economy, the market and the state can be expected to generate equilibria (cf. Aoki, 2001) which are upset by knowledge-based innovations (Nelson \& Winter, 1977,

\footnotetext{
${ }^{1}$ See at http://www.iamsterdam.com/nl/economic-development-board/over-edba/visie-ambitie/hoe-werken-we (Retrieved on January 23, 2012).
} 
1982; Schumpeter, 1939). Alternatively, when the state and its knowledge infrastructure constrict market forces (as in the former Soviet Union), a suboptimal lock-in can be sustained for considerable periods of time. The interaction of three (analytically independent) subdynamics, however, can destabilize, hyper-stabilize, meta-stabilize, or eventually globalize a relatively stabilized system, and thus change the system at the regime in terms of lock-ins and pathdependencies (Dolfsma \& Leydesdorff, 2009; Dosi, 1982; Viale, 2010).
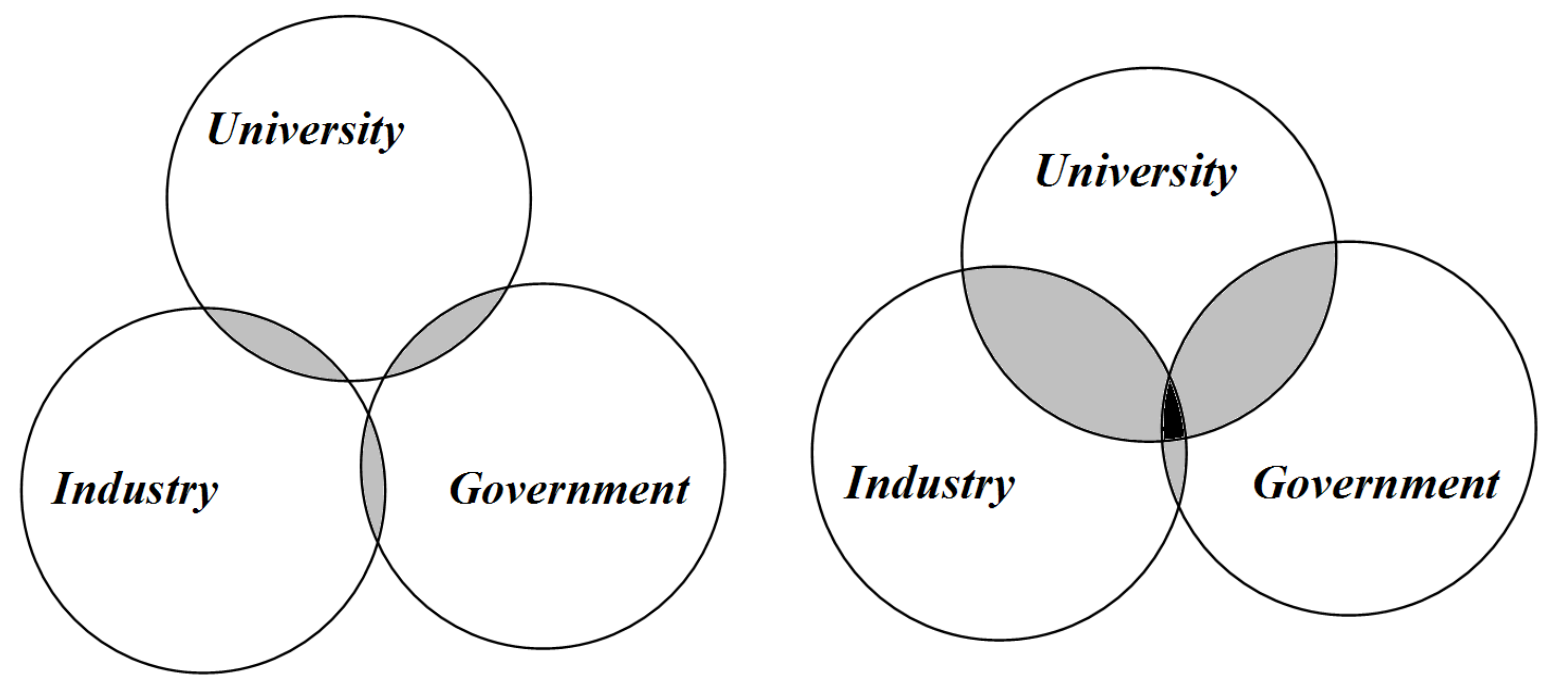

Figure 1: A Triple Helix configuration with negative and positive overlap among the three subsystems.

The Triple Helix model of university-industry-government relations is depicted in Figure 1 as alternating between bilateral and trilateral coordination mechanisms or-in institutional termsspheres. The systems remain in transition because each of the partner institutes also develops its own (differentiating) mission. Thus, a trade-off can be generated between integration and differentiation, and new systems in terms of possible synergies can be explored and potentially shaped. As the various bilateral translations function, a Triple Helix overlay can also be expected to develop as a system of meaning exchanges among differently coded expectations (Figure 2). 


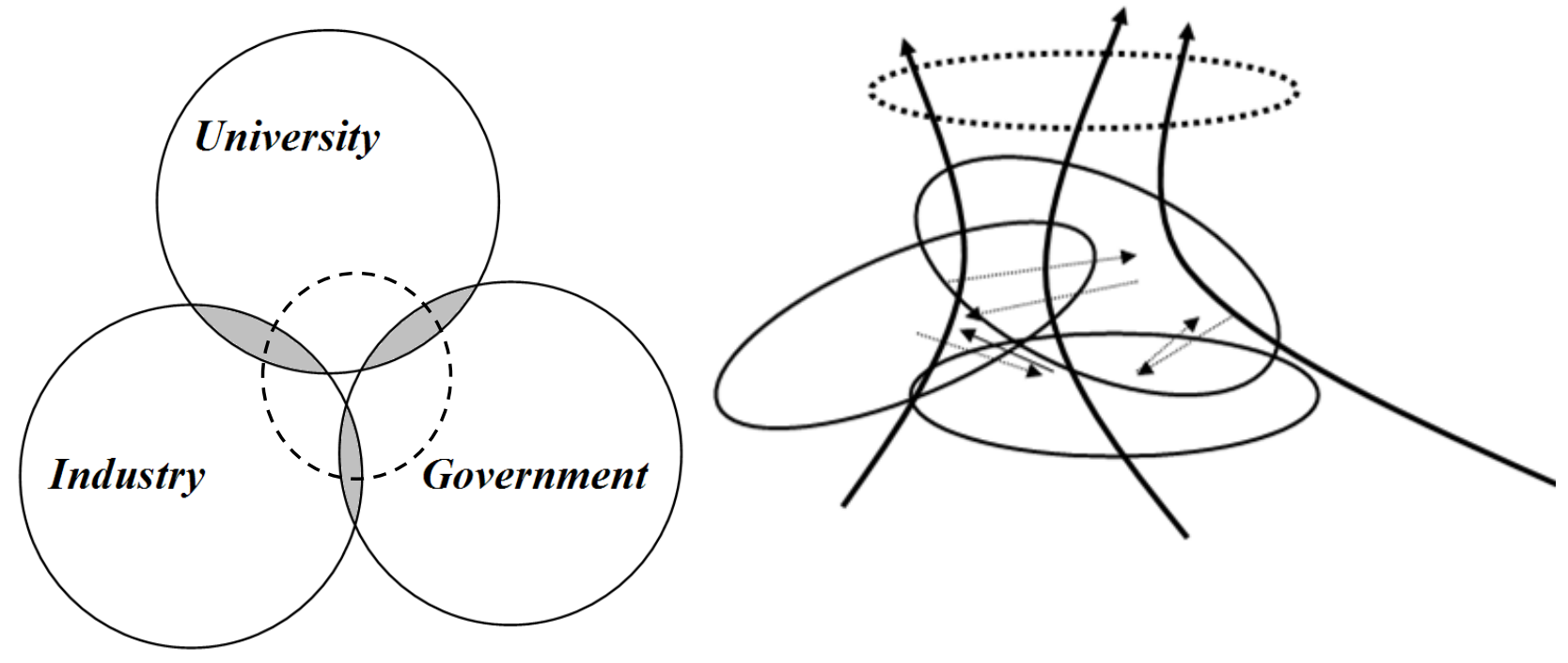

Figure 2: A differentiated Triple Helix with dynamic overlay

If one envisages the overlay (in Figure 2a) as hovering above the sheet, one can imagine a tetrahedron emerging from the bottom with four (three plus one) different types of communications involved. Political, scientific, and economic exchanges are different, but these media (e.g., power, truth, and money; Luhmann, 1995) can also be exchanged. In the overlay, translations among the various media can further be invented and developed.

Etzkowitz \& Leydesdorff (2000) specified the top-level overlay as a subdynamic and therefore differently from the specification of "Mode 2" by Gibbons et al. (1994; cf. Nowotny et al., 2001). "Mode-2" replaces "Mode-1," but a subdynamic functions among other subdynamics. The complex system can operate "transdisciplinarily" and one can translate contexts of discovery and justification into contexts of application (and vice versa), without damaging the integrity of the underlying processes. This imaginative restructuring may loosen existing boundaries at the 
institutional level and thus begin to reshape "systems of innovation." Unlike discussions about

national (Lundvall, 1988; Nelson, 1993) or regional (Braczyk et al., 1998) systems of innovation, the Triple Helix model enables us to consider empirically whether specific dynamics (e.g., synergies) among the three composing media emerge at national and/or regional levels. In other cases sectors and/or technologies (e.g., biotechnology) may be more relevant systems of reference for innovations than geographical units of analysis (Carlsson, 2006).

\section{Globalization: a transformation of the Triple Helix?}

In the case of Japan, for example, and using a specific operationalization, Leydesdorff \& Sun (2009) found that since the opening of China and the demise of the Soviet Union (1991) — both major changes in international competition - the national system of Japan has increasingly become a retention mechanism for international relations. Thus, a further differentiation between the national and the global level emerged in this explanation. In principle, the Triple Helix indicator - that is, the mutual information among three dimensions — can be extended to more than three dimensions (Kwon et al., 2012).

In a study about Hungary, Lengyel \& Leydesdorff (2011) found that its national system of innovations fell into three regional systems of innovation following the transition of the 1990s and the accession to the EU in 2004. The authors distinguish: (i) a metropolitan area around Budapest, (ii) a knowledge-based innovation system in the western part of the country which is integrated into other EU countries, and (iii) an eastern part of the country where the old (stateled) dynamics still prevail. The national level no longer adds synergy to these three regional systems. 
The roles of the academic, industrial, and governmental contributions are also not given. The central role of universities in many $\mathrm{TH}$ studies is based on the assumption that this system is more adaptive than the others because of the continuous flux of students (Shinn, 2002). In a recent study of Norway, however, Strand \& Leydesdorff (in preparation) found foreign direct investment via the offshore (marine and maritime) industries in the Western part of the country to be a greater source of synergy in the knowledge-based developments of regions than the university environments of the major centers in Trondheim and Oslo.

Two conclusions can be drawn from these nation-based studies: $(i)$ medium-tech industry is more important for synergy than high-tech, and (ii) the service sector tends to uncouple from geographical location because a knowledge-intensive service is versatile and not geographically constrained. These conclusions accord with the emphasis in the literature on embeddedness (Cohen \& Levinthal, 1989) and the footlooseness of high-tech industries (Vernon, 1979). Certain Italian industrial districts, for example, while very innovative, are under the continuous threat of deindustrialization because incumbent multinational corporations may buy and relocate new product lines (Beccatini, 2003; dei Ottati, 2003). In institutional analyses that focus on local and regional development using the Triple-Helix model, the structural effects of globalization are sometimes backgrounded.

\section{Different versions of the Triple Helix model}

The Triple Helix (TH) can be considered as an empirical heuristics which uses as explanantes not only economic forces (e.g., Schumpeter, 1939; Nelson \& Winter, 1982), and legislation and 
regulation by (regional or national) governments (e.g., Freeman, 1987; Freeman \& Perez, 1988), but also the theoretically endogenized dynamics of transformations by science-based inventions and innovations (Noble, 1977; Whitley, 1984). The TH model does not exclude focusing on two of the three dynamics - for example, in studies of university-industry relations (Clarke, 1998; Etzkowitz, 2002) or as in the "variety of capitalism" tradition (Hall \& Soskice, 2001)—but the third dynamics should at least be declared as another source of variation.

TH models can be elaborated in various directions. Firstly, the networks of university-industrygovernment relations can be considered as neo-institutional arrangements which can be made the subject of social network analysis. This model can also be used for policy advice about network development, for example in the case of transfer of knowledge and the incubation of new industry. The new and potentially salient role of universities in knowledge-based configurations can then be explored in terms of different sectors, regions, countries, etc. (Godin \& Gingras, 2000; Shinn, 2002). Over the past ten years, this neo-institutional model has also been developed into a discourse about "entrepreneurial universities" (Etzkowitz, 2002; Mirowski \& Sent, 2007). Regions are then considered as endowed with universities that can be optimized for a third mission, and different from higher education and internationally oriented research.

Secondly, the networks span an architecture in which each relation occupies a position. One can thus obtain a systems perspective on knowledge-based innovation in a hypothesized space; this theoretical construct — the knowledge-based economy—can be informed by systematic data analysis (e.g., Leydesdorff \& Fritsch, 2006). 


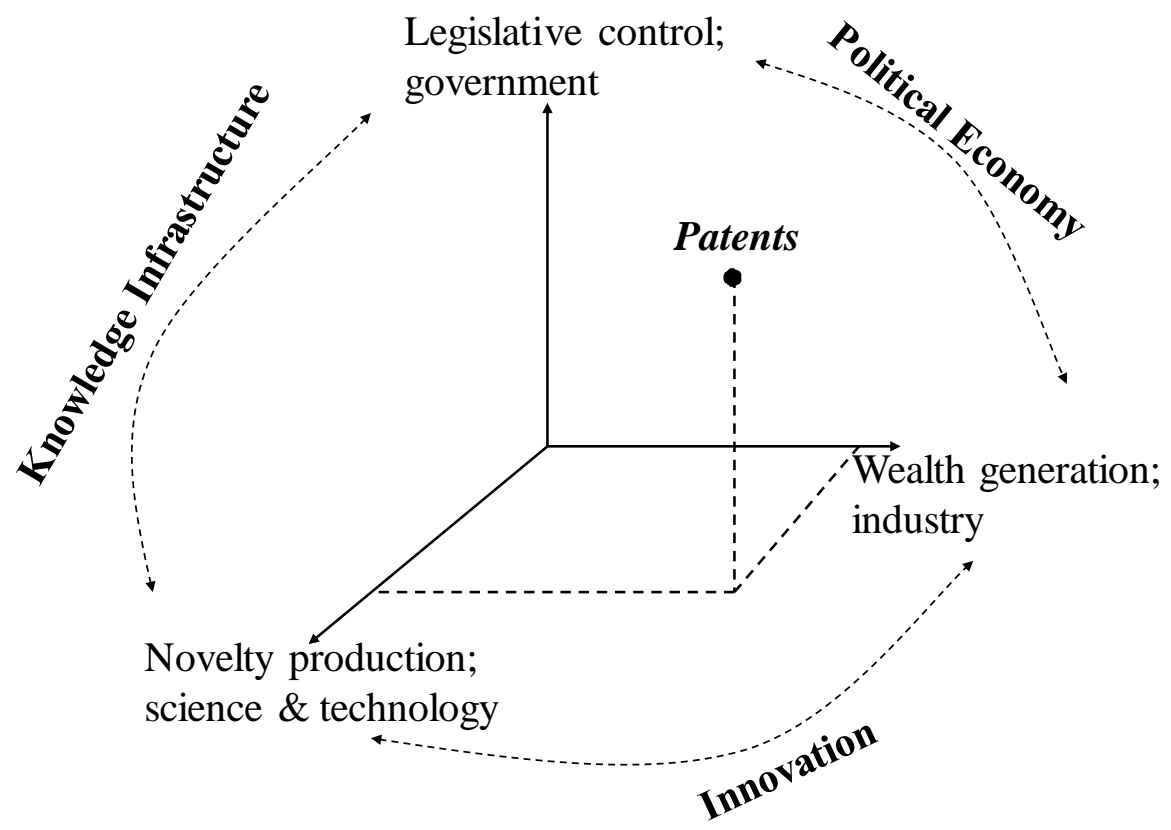

Figure 3: Patents as events in the three-dimensional space of Triple Helix interactions. (Source: Leydesdorff, 2010, at p. 370.

In Figure 3, patents are considered as positioned in terms of the three social coordination mechanisms of (1) wealth generation on the market by industry, (2) legislative control by government, and (3) novelty production in academia. Whereas patents are output indicators for science and technology, they function as input into the economy. Their main function, however, is to provide legal protection for intellectual property. In other words, events in a knowledgebased economy can be positioned in this three-dimensional space of industry, government, and academia. When events (e.g., patents) can also circulate, a three-way interaction can be expected. This knowledge-based economy contributes to the political economy by ensuring that the social organization of knowledge as R\&D is endogenized into the systems dynamics. 


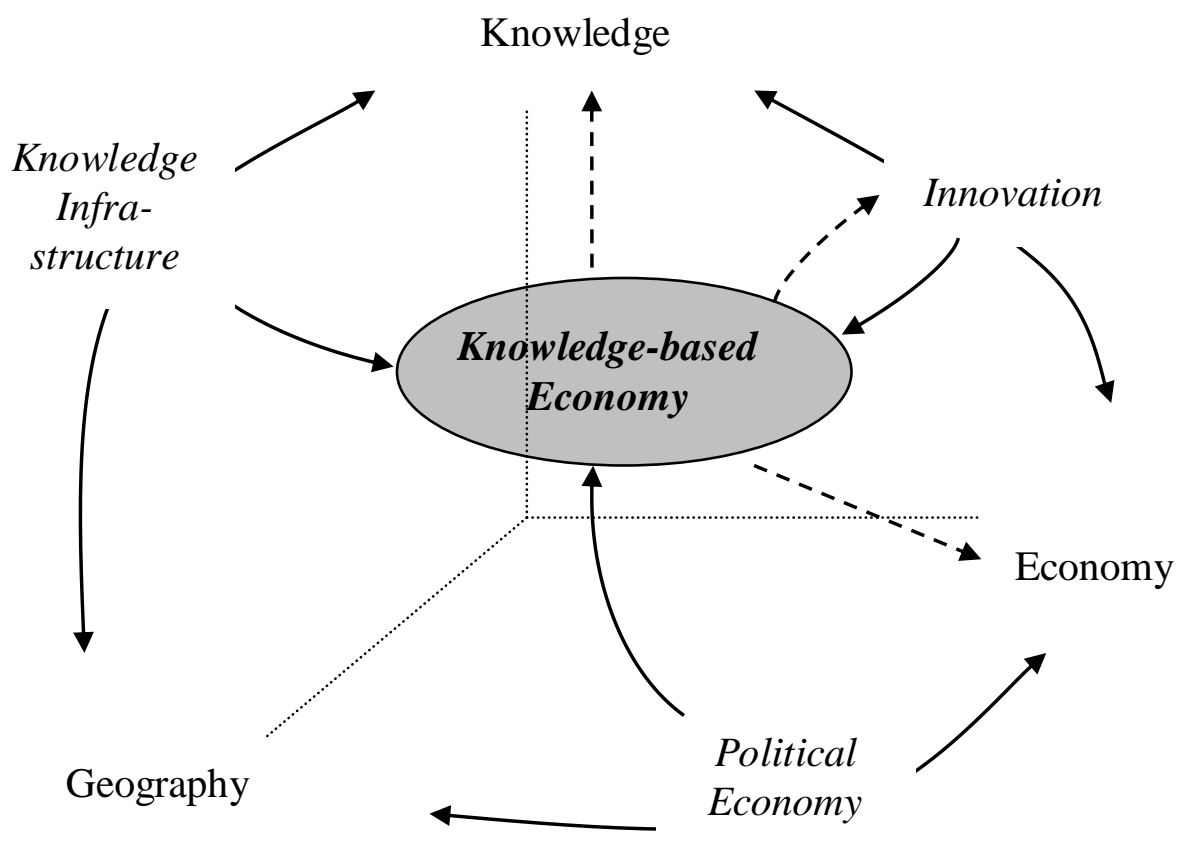

Figure 4: The first-order interactions generate a knowledge-based economy as a next-order system. (Source: Leydesdorff, 2010, at p. 379.)

The three functions in Figure 3 can also be considered as interaction terms among relational exchange processes (e.g., in an economy), political positions in a bordered unit of analysis (e.g., a nation), and the reflexive and transformative dynamics of knowledge. When these interaction terms exhibit second-order interaction, a knowledge-based economy can increasingly be shaped (Foray, 2004; Leydesdorff, 2006).

In my opinion, the crucial research question is under which condition s do the three functions operate synergetically, to what extent or at which level, and at what price? Is a country or region able to retain "wealth from knowledge" and/or "knowledge from wealth" (as in the case of oil revenues)? Such a synergy can be expected to perform a life-cycle. In the initial stage of emergence, "creative destruction" of the relevant parts of the old arrangements is the driving 
force. New entrants (scientists, entrepreneurs) can be expected to attach themselves preferentially to the originators - the innovation organizers — of the new developments.

In addition to "creative destruction" as typical for Schumpeter Mark I, Soete \& Ter Weel (1999) proposed considering "creative agglomeration" as typical of the competition among corporations. This changes the dynamics of development in the later stage of development, and is sometimes called "Schumpter Mark II" (Freeman \& Soete, 1997; Gay, 2010). In a bibliometric study of the diffusion of the new technology of RNA interference (Fire et al., 1998; Sung \& Hopkins, 2006), Leydesdorff \& Rafols (2011) found a change of preferential attachments from the inventors in the initial stage to emerging "centers of excellence" at a later stage. In the patent market, however, a quasi-monopolist was found (Leydesdorff \& Bornmann, in preparation) located in Colorado, whereas the research centers of excellence were concentrated in major cities such as London, Boston, and Seoul. Drug development requires a time horizon different from that required by the application of the technique in adjacent industries, such as the production of reagents for laboratories (Lundin, 2011).

In other words, the new technologies can move along trajectories in all three relevant directions and with potentially different dynamics. The globalization of the research front requires an uncoupling from the originators and a transition from Mode-1 to Mode-2 research in order to make the technique mutable (Latour, 1987). From this perspective, "Mode-1" and "Mode-2" are no longer considered as general systems characteristics of society and policy making, but as stages in the life-cycles of technological transformations. An analogon of Schumpeter Mark I 
and Mark II within the domain of organized knowledge production and control can thus be specified.

Universities are poorly equipped for patenting (Leydesdorff \& Meyer, 2010). Some of the original patents may profitably be held by academia. In the case of RNA interference, for example, two original US-patents ("Tuschl-I" and "Tuschl-II") were co-patented by MIT and the Max Planck Society in Germany (MIT Technology Licensing Office, 2006), but a company was founded as a spin-off to further develop the technology. As noted, the competition thereafter shifted along a commercial trajectory. In summary, whereas one can expect synergies to be constructed, the consequent system "self-organizes" in terms of relevant selection environments, while leaving behind institutional footprints. Three dimensions are important: the economic, political, and socio-cognitive potentials for change. Both local integrations and global pressures for differentiation can continuously be expected.

\section{Research strategies}

What is the contribution of these models in terms of providing heuristics to empirical research? First, the neo-institutional model of arrangements among different stakeholders can be used in case study analysis. Case studies can be enriched by addressing the relevance of the three major dimensions of the model on an equal footing ex ante. Research can then inform us about specifics, such as path-dependencies (e.g., Etzkowitz et al., 2000; Viale \& Campodall'Orto, 2002). Thus, the Triple Helix perspective does not disclaim the legitimacy of studying, for example, bi-lateral academic-industry relations or government-university policies. However, one can expect more interesting results by studying the interactions among the three subdynamics. 
Secondly, the model can be informed by the increasing understanding of complex dynamics and simulation studies from evolutionary economics (e.g., Malerba et al., 1999; Windrum, 1999). Thirdly, the Triple Helix model adds to the meta-biological models of evolutionary economics the sociological notion of meaning being exchanged among the institutional agents (Leydesdorff, 2011; Luhmann, 1995). Finally, on the normative side of developing options for innovation policies, the Triple Helix model provides us with an incentive to search for mismatches between the institutional dimensions in the arrangements and the social functions performed by these arrangements.

The frictions between the two layers (knowledge-based expectations and institutional interests), and among the three domains (economy, science, and policy) provide a wealth of opportunities for puzzle solving and innovation. The evolutionary regimes are expected to remain in transition as they are shaped along historical trajectories. A knowledge-based regime continuously upsets the political economy and the market equilibria as different subdynamics. Conflicts of interest can be deconstructed and reconstructed, first analytically and then perhaps also in practices in the search for solutions to problems of economic productivity, wealth retention, and knowledge growth.

The rich semantics of partially conflicting models reinforces a focus on solving puzzles among differently codified communications reflexively. The lock-ins and bifurcations are systemic, that is, largely beyond control; further developments are based on the variation and the selforganizing dynamics of interactions among the three selection environments. These subdynamics 
can also be considered as different sources of variance which disturb and select from one

another. Resonances among selections shape trajectories in co-evolutions, and the latter may

recursively — that is, selectively_drive the system into new regimes. This neo-evolutionary

framework assumes that the processes of both integration and differentiation in university-

industry-government relations remain under reconstruction.

\section{References}

Almeida, M. (2005). The evolution of the incubator movement in Brazil. International Journal of Technology and Globalisation, 1(2), 258-277.

Aoki, M. (2001). Towards a Comparative Institutional Analysis. Cambridge, MA: MIT Press.

Beccatini, G. (2003). The Development of Tuscany: Industrial Districts. In G. Beccatini, M. Bellandi, G. dei Ottati \& F. Sforzi (Eds.), From Industrial Districts to Local

Development: An Itinerary of Research (pp. 11-28). Cheltenham, UK; Northhampton, MA: Edward Elgar.

Braczyk, H.-J., Cooke, P., \& Heidenreich, M. (Eds.). (1998). Regional Innovation Systems. London/ Bristol PA: University College London Press.

Braczyk, H.-J., Cooke, P., \& Heidenreich, M. (Eds.). (1998). Regional Innovation Systems. London/ Bristol PA: University College London Press.

Bunders, J. F. G., Broerse, J. E. W., \& Zweekhorst, M. B. M. (1999). The triple helix enriched with the user perspective: A view from Bangladesh. The Journal of Technology Transfer, 24(2), 235-246.

Carlsson, B. (2006). Internationalization of Innovation Systems: A Survey of the Literature. Research Policy, 35(1), 56-67.

Carlsson, B. (2006). Internationalization of Innovation Systems: A Survey of the Literature. Research Policy, 35(1), 56-67.

Clark, B. R. (1998). Creating Entrepreneurial Universities: Organization Pathways of Transformation. Guildford, UK: Pergamon.

Cohen, W. M., \& Levinthal, D. A. (1989). Innovation and Learning: The Two Faces of R \& D. The Economic Journal, 99(397), 569-596.

Cooke, P., \& Leydesdorff, L. (2006). Regional Development in the Knowledge-Based Economy: The Construction of Advantages. Journal of Technology Transfer, 31(1), 5-15.

Cooke, P., \& Leydesdorff, L. (2006). Regional Development in the Knowledge-Based Economy: The Construction of Advantages. Journal of Technology Transfer, 31(1), 5-15.

dei Ottati, G. (2003). Local Governance and Industrial Districts' Competitive Advantage. In G. Beccatini, M. Bellandi, G. dei Ottati \& F. Sforzi (Eds.), From Industrial Districts to Local Development: An Itinerary of Research (pp. 184-209). Cheltenham, UK/ Northhampton, MA: Edward Elgar. 
Dolfsma, W., \& Leydesdorff, L. (2009). Lock-in \& Break-out from Technological Trajectories: Modeling and policy implications. Technological Forecasting and Social Change, 76(7), 932-941.

Dosi, G. (1982). Technological Paradigms and Technological Trajectories: A Suggested Interpretation of the Determinants and Directions of Technical Change. Research Policy, 11(3), 147-162.

Etzkowitz, H. (1994). Academic-Industry Relations: A Sociological Paradigm for Economic Development. In L. Leydesdorff \& P. van den Besselaar (Eds.), Evolutionary Economics and Chaos Theory: New Directions in Technology Studies (pp. 139-151). London, etc.: Pinter.

Etzkowitz, H. (2002). MIT and the Rise of Entrepreneurial Science. London: Routledge.

Etzkowitz, H., \& Leydesdorff, L. (1995). The Triple Helix---University-Industry-Government Relations: A Laboratory for Knowledge-Based Economic Development. EASST Review 14, 14-19.

Etzkowitz, H., \& Leydesdorff, L. (1997). Universities and the Global Knowledge Economy: A Triple Helix of University-Industry-Government Relations. London: Pinter.

Etzkowitz, H., \& Leydesdorff, L. (1998). The Endless Transition: A "Triple Helix" of University-Industry-Government Relations, Introduction to a Theme Issue. Minerva, 36, 203-208.

Etzkowitz, H., \& Leydesdorff, L. (2000). The Dynamics of Innovation: From National Systems and 'Mode 2' to a Triple Helix of University-Industry-Government Relations. Research Policy, 29(2), 109-123.

Etzkowitz, H., Webster, A., Gebhardt, C., \& Terra, B. R. C. (2000). The future of the university and the university of the future: evolution of ivory tower to entrepreneurial paradigm. Research Policy, 29(2), 313-330.

Fire, A., Xu, S. Q., Montgomery, M. K., Kostas, S. A., Driver, S. E., \& Mello, C. C. (1998). Potent and specific genetic interference by double-stranded RNA in Caenorhabditis elegans. Nature, 391(6669), 806-811.

Foray, D. (2004). The Economics of Knowledge. Cambridge, MA/London: MIT Press.

Freeman, C. (1987). Technology, policy, and economic performance: lessons from Japan. London: Pinter Publishers.

Freeman, C., \& Perez, C. (1988). Structural crises of adjustment, business cycles and investment behaviour. In G. Dosi, C. Freeman, R. Nelson, G. Silverberg \& L. Soete (Eds.), Technical Change and Economic Theory (pp. 38-66). London: Pinter.

Freeman, C., \& Soete, L. (1997). The Economics of Industrial Innovation. London: Pinter.

Gay, B. (2010). Innovative network in transition: From the fittest to the richest. Available at http://papers.ssrn.com/sol3/papers.cfm?abstract_id=1649967.

Gibbons, M., Limoges, C., Nowotny, H., Schwartzman, S., Scott, P., \& Trow, M. (1994). The new production of knowledge: the dynamics of science and research in contemporary societies. London: Sage.

Godin, B., \& Gingras, Y. (2000). The place of universities in the system of knowledge production. Research Policy, 29(2), 273-278.

Hall, P. A., \& Soskice, D. W. (Eds.). (2001). Varieties of Capitalism: The Institutional Foundations of Comparative Advantage. Oxford, etc.: Oxford University Press.

Jacob, M. (2006). Utilization of social science knowledge in science policy: Systems of Innovation, Triple Helix and VINNOVA. Social Science Information, 45(3), 431-462. 
Krippendorff, K. (2009). Information of Interactions in Complex Systems. International Journal of General Systems, 38(6), 669-680.

Kwon, K. S., Park, H. W., So, M., \& Leydesdorff, L. (2012). Has Globalization Strengthened South Korea's National Research System? National and International Dynamics of the Triple Helix of Scientific Co-authorship Relationships in South Korea. Scientometrics, 90(1), 163-175; doi: 10.1007/s11192-11011-10512-11199

Latour, B. (1987). Science in Action. Milton Keynes: Open University Press.

Lengyel, B., \& Leydesdorff, L. (2011). Regional innovation systems in Hungary: The failing synergy at the national level. Regional Studies, 45(5), 677-693.

Leydesdorff, L. (1995). The Challenge of Scientometrics: The development, measurement, and self-organization of scientific communications. Leiden: DSWO Press, Leiden University; at http://www.universal-publishers.com/book.php?method=ISBN\&book=1581126816.

Leydesdorff, L. (2006). The Knowledge-Based Economy: Modeled, Measured, Simulated. Boca Raton, FL: Universal Publishers.

Leydesdorff, L. (2011). "Meaning" as a sociological concept: A review of the modeling, mapping, and simulation of the communication of knowledge and meaning. Social Science Information, 50(3-4), 1-23.

Leydesdorff, L., \& Bornmann, L. (in preparation). Mapping (USPTO) Patent Data using Overlays to Google Maps.

Leydesdorff, L., \& Fritsch, M. (2006). Measuring the Knowledge Base of Regional Innovation Systems in Germany in terms of a Triple Helix Dynamics. Research Policy, 35(10), 1538-1553.

Leydesdorff, L., \& Meyer, M. (2010). The Decline of University Patenting and the End of the Bayh-Dole Effect. Scientometrics, 83(2), 355-362.

Leydesdorff, L., \& Rafols, I. (2011). How Do Emerging Technologies Conquer the World? An Exploration of Patterns of Diffusion and Network Formation. Journal of the American Society for Information Science and Technology, 62(5), 846-860.

Leydesdorff, L., \& Sun, Y. (2009). National and International Dimensions of the Triple Helix in Japan: University-Industry-Government versus International Co-Authorship Relations. Journal of the American Society for Information Science and Technology 60(4), 778-788.

Lowe, C. U. (1982). The Triple Helix- NIH, industry, and the academic world. The Yale Journal of Biology and Medicine, 55(3-4), 239-246.

Luhmann, N. (1995). Social Systems. Stanford, CA: Stanford University Press.

Lundin, P. (2011). Is silence still golden? Mapping the RNAi patent landscape. Nature Biotechnology, 29(6), 493-497.

Lundvall, B.- $\AA$. (1988). Innovation as an interactive process: from user-producer interaction to the national system of innovation. In G. Dosi, C. Freeman, R. Nelson, G. Silverberg \& L. Soete (Eds.), Technical Change and Economic Theory (pp. 349-369). London: Pinter.

Lundvall, B.-A. (1988). Innovation as an interactive process: from user-producer interaction to the national system of innovation. In G. Dosi, C. Freeman, R. Nelson, G. Silverberg \& L. Soete (Eds.), Technical Change and Economic Theory (pp. 349-369). London: Pinter.

Malerba, F., Nelson, R., Orsenigo, L., \& Winter, S. (1999). 'History-firendly' Models of Industry Evolution: The Computer Industry. Industrial and Corporate Change, 8(1), 335.

Mirowski, P., \& Sent, E. M. (2007). The Commercialization of Science, and the Response of STS. In E. J. Hackett, O. Amsterdamska, M. Lynch \& J. Wajcman (Eds.), Handbook of 
Science, Technology and Society Studies (pp. 635-689). Cambridge, MA/London: MIT Press.

MIT Technology Licensing Office (2006). Licensing for RNAi Patents, at http://web.mit.edu/tlo/www/industry/RNAi_patents_tech.html (Retrieved on Oct. 19, 2011).

Nelson, R. R. (Ed.). (1993). National Innovation Systems: A comparative analysis. New York: Oxford University Press.

Nelson, R. R. (Ed.). (1993). National Innovation Systems: A comparative analysis. New York: Oxford University Press.

Nelson, R. R., \& Winter, S. G. (1977). In Search of Useful Theory of Innovation. Research Policy, 6, 35-76.

Nelson, R. R., \& Winter, S. G. (1982). An Evolutionary Theory of Economic Change. Cambridge, MA: Belknap Press of Harvard University Press.

Noble, D. (1977). America by Design. New York: Knopf.

Nowotny, H., Scott, P., \& Gibbons, M. (2001). Re-Thinking Science: Knowledge and the Public in an Age of Uncertainty. Cambridge, etc: Polity.

Park, H. W., \& Leydesdorff, L. (2010). Longitudinal trends in networks of university-industrygovernment relations in South Korea: The role of programmatic incentives. Research Policy, 39(5), 640-649.

Rothwell, R., \& Zegveld, W. (1981). Industrial Innovation and Public Policy. London: Pinter.

Saad, M., Zawdie, G., \& Malairaja, C. (2008). The triple helix strategy for universities in developing countries: the experiences in Malaysia and Algeria. Science and Public Policy, 35(6), 431-443.

Sábato, J. (1975). El pensamiento latinoamericano en la problemática ciencia-technologíadesarrollo-dependencia. Buenos Aires: Paidós.

Schumpeter, J. ([1939], 1964). Business Cycles: A Theoretical, Historical and Statistical Analysis of Capitalist Process. New York: McGraw-Hill.

Shinn, T. (2002). The Triple Helix and New Production of Knowledge : Prepackaged Thinking on Science and Technology. Social Studies of Science, 32(4), 599-614.

Soete, L., \& ter Weel, B. (1999). Schumpeter and the knowledge-based economy: On technology and competition policy. Research Memoranda 004. MERIT, Maastricht Economic Research Institute on Innovation and Technology.

Strand, O., \& Leydesdorff, L. (in preparation). Where is Synergy in the Norwegian Innovation System Indicated? Triple Helix Relations among Technology, Organization, and Geography.

Sung, J. J., \& Hopkins, M. M. (2006). Towards a method for evaluating technological expectations: Revealing uncertainty in gene silencing technology discourse. Technology Analysis \& Strategic Management, 18(3), 345-359.

Vernon, R. (1979). The Product Cycle Hypothesis in a New International Environment. Oxford Bulletin of Economics and Statistics, 41(4), 255-267.

Viale, R., \& Campodall'Orto, S. (2002). An evolutionary Triple Helix to strengthen academyindustry relations:suggestions from European regions. Science and Public Policy, 29(3), 154-168.

Viale, R., \& Pozzali, A. (2010). Complex Adaptive Systems and the Evolutionary Triple Helix. Critical Sociology, 36(4), 575-594. 
Whitley, R. D. (1984). The Intellectual and Social Organization of the Sciences. Oxford: Oxford University Press.

Windrum, P. (1999). Simulation models of technological innovation: a review. American Behavioral Scientist, 42(10), 1531-1550. 